Editorial

\title{
Women Architects on the Road to an Egalitarian Profession-The Portuguese and Spanish Cases
}

\author{
Lucía C. Pérez-Moreno ${ }^{1, *(1)}$ and Patrícia Santos Pedrosa ${ }^{2,3}$ (1) \\ 1 School of Engineering and Architecture, Zaragoza University, 50018 Zaragoza, Spain \\ 2 Interdisciplinary Center of Gender Studies, University of Lisbon, 1300-663 Lisbon, Portugal; \\ ppedrosa@iscsp.ulisboa.pt \\ 3 Department of Civil Engineering and Architecture, University of Beira Interior, 6201-001 Covilhã, Portugal \\ * Correspondence: lcperez@unizar.es
}

Received: 6 February 2020; Accepted: 19 February 2020; Published: 23 March 2020

\begin{abstract}
The 1970s was a key decade in the path towards democracy in the Iberian Peninsula. Portugal and Spain suffered deep social, cultural and political changes, with Salazar's and Franco's Totalitarian Regimes ending in 1974 and 1975 respectively. In both countries, located side-by-side in the Western end of Southern Europe, democracy was finally established, marking a turning point in the liberties of all Iberian citizens, but especially in regard to women's life and work. As the Editorial of the Special Issue 'Becoming a Gender Equity Democracy: Women and Architecture Practice in Spain and Portugal', this text aims to briefly present this panorama to appreciate the particularities of Portugal and Spain in relation with the delay incorporation of women to the architecture profession. It explains the gender stereotypes of Salazar's and Franco's Regime in order to understand the discrimination against women that they produced and how it maintained women far from the architecture profession. Therefore, it provides useful data on the incorporation of women into architectural studies in order to understand the feminization of this gendered profession in both countries. This Special Issue aims to create an opportunity for researchers and scholars to present discussions and ongoing research on how democracy affected women that wanted to practice architecture as well as architectural analysis of women architects.
\end{abstract}

Keywords: Spanish architecture; Portuguese architecture; history of women; gender studies; architecture profession

\section{Introduction}

The 1970s was a key decade in the fight for democracy in the Iberian Peninsula. Portugal and Spain suffered deep social, cultural and political changes, with Salazar's and Franco's totalitarian regimes ending in 1974 and 1975 respectively. In the following years, both countries were immersed in political processes that, although different, shared the same purpose of building democratic nations that guaranteed a broad set of egalitarian liberties and rights for men and women. For Portuguese and Spanish women, and especially for those who wanted to practice architecture, democracy was a crucial condition in order to access and practice this profession. During these years, the first books on the history of women in architecture were published. Cole (1973) and Torre (1977) articulated their respective readings of how women had joined the profession. Almost fifty years later, it is still necessary to vindicate studies on the work done by women in architecture as well as to analyse the particularities of each country according to its patriarchal tradition and architectural culture.

This special issue aims to present reflexions on the cases of Portugal and Spain, two countries located side-by-side at the Western end of Southern Europe that share a historical patriarchal culture based on their totalitarian regimes. For a reader unaware of the particularities of Spanish and 
Portuguese culture, it might be surprising, in comparison with the United States, for example, that such a low number of women studied architecture in both countries from the 1960s to the 1980s. Why was there a delay in achieving comparable numbers? This paper presents a general background on the gender stereotypes promulgated by Salazar's and Franco's regimes, an essential consideration in understanding why women decided not to study architecture. With the advent of democracy, juridical reforms affected women's rights and family structures and women were considered equal to men in law. Both countries' social transformations fostered an increase in the number of women graduating from universities, making the last two decades of the twentieth century the moment in which the incorporation of women into the architecture profession could be considered a major transformation of this discipline in both countries.

\section{Salazar's and Franco's Regime: Gender Stereotypes and Discrimination against Women}

In Portugal, the 1926 coup d'état put an end to the First Republic and initiated the process that led, in 1933, to the new Constitution and the Estado Novo dictatorship with António de Oliveira Salazar (1889-1970) as head of government. The Constitution, together with the Colonial Act and the corporate State, established over four decades of order based on the authority of the State, clear hierarchical relations between the metropole and the colonies, and an economic organization where capital and labour harmoniously contributed to the higher interests of the nation (Oliveira 1992, p. 27). Ten years later, on 18 July 1936, a failed coup d'état triggered the Spanish Civil War (1936-1939). A part of the Spanish army revolted against the government of the Second Spanish Republic (1931-1939) and the war ended with a regime led by the Spanish general and dictator Francisco Franco (1939-1975) who assumed the title of Caudillo of Spain.

Several social history studies on gender indicate that women were exalted as keepers of the domestic sphere and pillars of family life in both regimes. According to Salazar, women were "the cornerstone of a well-organized society", a defence against social ruin and anarchy (Ferro 1935, pp. 132-35). Likewise, Franco's Regime, with the support of the Catholic Church and the Falange Women's organization, promulgated a clearly gender biased education for women, constraining them from entering universities and finding jobs (Pérez-Moreno 2016).

In a position that reflected similarities with the other dictators who had been sprouting all over Europe since the 1930s, Salazar and Franco tried to glorify the role of women in the new society they aspired to build. As the historian Irene Pimentel wrote about the Portuguese regime-which could be equally applied to Franco's regime-this role was supported by three essential ideas about women within the regime: "the apparent unequal value of the different roles; the distinction between single and married women, and the division of spaces-public/private-between men and women" (Pimentel 2015a, p. 210). Alongside other regime strategies, this meant that, in Portugal, as in neighbouring Spain, "individual men have a stable future as heads of families" (Ginsborg 2003, p. 198). Like all reactionary regimes, with powerful religious support "the subordination of women to men [was] one of its basic components (ideological, political and economic), and one of its pillars" (Sarasúa and Molinero 2009). Both regimes' objective was to prevent female emancipation by ensuring their main function in society was confined within the home, taking care of domestic tasks and looking after the children and old people.

During Franco's Regime, the Law established that canonical matrimony was obligatory for both partners when at least one of them professed the Catholic faith (Picontó 1997). On 23 September 1939, a new law repealed the divorce law approved in the Second Republic in 1932, and declared all divorce rulings null and void. The hostility to divorce emanated from the regime's official endorsement of Catholicism as the state religion, which established in its Law on the Principles of the National Movement (17 May 1958) that "the Spanish nation considers the observance of the law of God as a mark of honour, according to the doctrine of the Holy Roman Catholic and Apostolic Church". As the Spanish historian Amparo Moreno later explained: "from birth, and throughout her life, the [Spanish] woman [was] subjected to an education process whose purpose [was] to make her accept, 
as something natural, the role that a capitalist and patriarchal society [gave] her: as housewife, that is, wife and mother at the service of the man" (Moreno 1977, p. 29). In the Employment Code of 1938, Franco's Regime settled the rhetorical promise to 'free the married woman from the workplace and factory', to restrict women's opportunities to earn a wage. In a similar manner, the 1933 Portuguese Constitution followed 19th-century Civil and Criminal Codes, and removed the equality in marriage established by the First Portuguese Republic. Under the law and ideology defined by the Estado Novo, women continue to have to obey their husbands and live in the family home. As wives, they were obliged to attend to the 'housekeeping' and provide "moral assistance as a way of strengthening and perfecting the family unit". On the other hand, the husband had full freedom to decide on family assets (Pimentel 2015a, p. 215). Therefore, some women were forbidden from marrying: nurses working in civil hospitals, flight attendants of TAP Air Portugal, telephone operators of the Anglo-Portuguese Telephone Company, and the female personnel of the Ministry of Foreign Affairs (Ferreira 2001, p. 28). In the case of female teachers, the 1936 decree-law declared that they needed an authorization from the Ministry of National Education in order to get married, and her suitors had to show "good moral and civil behaviour", as well as prove that they had "salaries or income comparable to those of the teacher". The Portuguese historian Irene Pimentel adds that the Estado Novo maintained what had been established by the First Republic concerning equal treatment in the case of adultery, but that on the issue of divorce, article 24 of the Concordata was followed until 1975, which prohibited divorce among those married by the Catholic Church (Pimentel 2015a, p. 216; 2015b, p. 377). In 1975 divorce was legalized in Portugal, and seven years later adultery was decriminalized. In Spain, under Franco's laws, only female adultery was considered a crime and punishable with up to six years in prison; it was decriminalized in 1978 with the advent of democracy, as well as divorce, finally legalized in 1981. In both regimes, for more than four decades, the legal subordination of married women reached such a magnitude that they were not even able to get a mortgage, purchase or sell property, among many other things, without their husband's consent.

As for voting rights, women's suffrage was recognized in 1931 in Spain, during the Second Republic, a right that both women and men would lose with Franco as Caudillo. Spaniards, women and men, would not vote again until 1977. In contrast, Portuguese women who were 'heads of the household', and later emancipated, acquired the right to vote in parish council elections in 1931. In the case of city council elections, in addition to the conditions mentioned above, only women who had a high-school education could vote. According to Pimentel, this right to vote came from the idea that women's votes guaranteed Salazar's election. This control of female suffrage, both as elected candidates and as voters, indicated that Salazar had intuited that only Portuguese Christian women could fight effectively "against demoralization". As Pimentel (2015a, pp. 216-18) highlights, it is clear that female suffrage was not a right conquered by women, but rather a decision decreed by the 'Dictator', who considered that some elite women could contribute to the fields of education and assistance.

\section{New Democracies as the Turning Point towards Gender Equality}

In 1975, with Francisco Franco's death on 20 November, Spain was plunged into a series of political changes and social upheaval known as the 'Transition'. In 1978, a year after the first democratic elections, the Spanish Constitution was approved by referendum and the country was finally defined as a Parliamentary Monarchy ${ }^{1}$ At the same time, the process of building the current Spanish state based on seventeen autonomous regions and two autonomous cities started. The country was administratively structured giving regional governments power to legislate in certain areas, and progressively decentralizing issues such as education and the governance of Universities. The late

1 It is considered that the transition to democracy ended in 1982 when the Social Democratic Political Party (PSOE) won a majority in the democratic elections and held power during the following four legislatures. 
1970s and the beginning of the 1980s was a time of hope for men and women to construct a free, democratic, egalitarian, secularized and politically pluralist country.

Throughout these decades, there were several critical voices against the oppressive situation of women, and the Regime's continuous struggle for women's rights and their entry into the workplace. Most of them were essentially linked to resistance movements to the dictatorship that were conscious of the arguments of American and Centre-European feminist's waves. These were years of feminist political activism (Larumbe 2004) with a growing number of women's associations and groups that actively fought for the recognition of women's rights. The Democratic Women's Movement (MDM, Movimiento Democrático de Mujeres), the National Association of Legaly Separated Women (ASMSL, Asociación Nacional de Mujeres Separadas Legalmente), and the Spanish Feminist Party (PFE, Partido Feminista de España), among others, were created in 1964, 1973 and 1975, respectively (Larumbe 2002). Most of them were fighting to gain further rights, such as the decriminalization of abortion and adultery, and the legalization of contraceptives and divorce (Pérez-Moreno 2016).

In Portugal, Oliveira Salazar stepped down as head of government in 1968 for health reasons, and was replaced by Marcello Caetano. This expected new moment, referred to as the Marcellist Spring, would simply turn out to be a continuation of the previous regime and not a period of relaxation as everyone had hoped. That year the Women's Democratic Movement (MDM) was born, from inside the Portuguese Communist Party (PCP), known for its strong anti-fascist activity. Operating within the confines of the enduring dictatorship but no longer clandestine, the MDM developed campaigns and initiatives against the colonial wars, supporting the release of the $\mathrm{PCP}^{\prime} \mathrm{s}$ female political prisoners, and universal preschool education. The presence of women in labour strikes, student struggles, vigils for peace and actions against war grew intensely (Pimentel 2015a, pp. 354-55). Seven years later, on 25 April 1974, the dictatorial and corporatist regime that had ruled Portugal for almost half a century was overthrown by a military coup planned and executed by the Armed Forces Movement (MFA), a clandestine organization created by young officers. That intervention, the Carnation Revolution, was accompanied by the spontaneous insurrection of the population, who took to the streets to enthusiastically participated in finally ousting the obdurate fascist regime. This led rapidly to the release of political prisoners, among other important consequences. A year later, on 25 April 1975, Portugal celebrated elections for the Constituent Assembly in order to draft a new Constitution that consolidated democracy in 1976. Portugal became a democratic and republican estate.

Both new Constitutions declared equality between men and women. In parallel, the ratification of the Universal Declaration of Human Rights rejected any discrimination based on sex. However, in both countries, cultural and social traditions continued specially those related with decision-making, professional opportunities, and working methods.

New Constitutions and the new demands of society involved an avalanche of regulations to adapt Spanish legislation to the 1978 Constitution, and Portuguese legislation to the 1976 Constitution. In the case of Spain, Franco's regime's civil, criminal, labour, and administrative codes were discriminatory and subordinated to the demands of a Catholic and confessional power (Picontó 1997, p. 112). The age of majority for women was reduced from 21 to 18 years old, and the age of emancipation was finally 16. The institution of marriage and the family underwent huge legal and social changes. The 1978 Constitution opened the way for secularization and religious pluralism in the regulation of the forms of matrimony; separation and dissolution of marriage was recognized as a right, and divorce was finally legalized (ibid., p. 113). At the same time, legislative reform placed the rights of the wife on the same level as those of the husband "in order to stabilize the economic-conjugal system and at the same time eliminated the most egregious provisions of the legislation which still prevailed in 1975 concerning the 'authority' of the husband with regard to the wife, and the resulting necessity for licences or the husband's authorization concerning the wife for almost everything" (ibid., p. 114). Indeed, the financial and civil equality of marriage partners and protection of the rights of the children was also recognized in the 1978 Spanish Constitution. As Teresa Picontó explained, it was a huge step for women rights "to establish joint parental authority as against the sole authority of the father in the pre-constitutional 
legislation". In the following decades, religious faith and the active practice of Catholicism decreased dramatically in Spain. From its zenith as a confessional country during Franco's Regime, by the early 1990s less than 26\% of Spaniards claimed to be practising Catholics (Gíner and Sarasa 1992). In the case of Portugal, at the end of 1975, "restrictions based on sex concerning citizens' voting rights" were abolished, which made them "universal, from the age of eighteen onwards". Every female organization of the Estado Novo was extinguished or abolished very rapidly, and, as a consequence of enormous social pressure, the prohibition on divorce for marriages celebrated by the Catholic Church was repealed in 1975. The implementation of universal governmental support for all children, both those born inside or outside of wedlock, was also relevant to move away from a corporatist idea of the family (Pimentel 2015b, pp. 376-78).

\section{Women's Education and Their Incorporation into Architectural Studies: The Spanish Case}

According to the Spanish Sociologist María Ángeles Durán, between 1940 and 1965, the active female population in Spain from the age of 15 to 65 grew from $8 \%$ to $17 \%$, even though women were $64 \%$ of the Spanish population in 1940 (63\% in 1965) (Durán 1972, p. 55). In fact, in 1940 the percentage of women attending studies in Spanish Universities was only 4\%; in 1967, it increased to $25 \%$. The majority of women who decided to study a degree in a University chose subjects considered to be more suitable for females, such as teaching or nursing; a decision influenced by a strong tradition educating men and women in gender stereotypes based on the Franco Regime's ideals in which segregated primary and secondary education was encouraged and the curriculum set for girls differed from that of boys. ${ }^{2}$ Girls studied subjects from the so-called 'Domestic Studies School' that prepared them to be wives, mothers and schoolteachers-the women's occupations par excellence (González Pérez 2009). Domestic Studies School was compulsory in primary and secondary education for girls. These subjects were not meant to be taken lightly. While girls were taught from a very young age in what was considered to be their main social role- the one of wife and mother-the courses in Domestic Studies School formed part of the examinations that girls had to pass to be admitted to higher degree studies in any Spanish University. Even though some women studied at the University, the country's general culture considered it proper that the women, as wives and daughters, should not work as a demonstration of the male's capacity to provide entirely for the needs of his family (Larumbe 2002). Furthermore, in the late sixties, $85.6 \%$ of Spanish women were married before the age of $29-10.5 \%$ before the age of $20,51.6 \%$ between the ages of 20 and 24, and 23.5\% between 25 and 29 years old (Durán 1972, p. 64).

It is significant that gender stereotypes upheld by Franco's regimen and supported by Catholic education, in addition to targeting women of higher education, boosted a stereotyped understanding of professions, which were considered as either feminine or masculine; architecture, engineering, law or military services being decidedly masculine. In 1974, the magazine Triunfo published a study on "The work of women in Spain" (Triunfo 1974), which showed that the percentage of women studying engineering or architecture in the academic year 1970-1971 was 2.8\% (Table 1) in contrast with $95.5 \%$ attending non-university studies (at that time), such as kindergarten education or $97.2 \%$ Social Services (Triunfo 1974, p. 32).

2 Four laws stand out in the early years of the Regime: the Middle School Reform Act (20 September 1938), the law that regulated the Ordination of the University (29 July 1943), the law of Primary Education (17 July 1945) and the law of Industrial Professional Education (16 July 1949). In the 1950s there were three other laws: the law on the Regulation of Secondary Education ('Ruiz Jiménez' Law, 26 February 1953), the law on School Construction (22 December 1953), the law on Technical Education (Law of 20 July 1957). Until the Law 14/1970, of 4 August, General Law of Education and Financing of the Educational Reform (LGE), the Spanish Educational System was not regulated and structured completely again. 
Table 1. Percentage of men and women starting University Studies in 1970, Spain.

\begin{tabular}{ccc}
\hline University Degree & Men (\%) & Women (\%) \\
\hline Arts & 37.7 & 62.3 \\
Philosophy \& Humanities & 44.1 & 55.9 \\
Pharmacy & 44.5 & 55.5 \\
Technical Schools & 97.2 & 2.8 \\
\hline \multicolumn{2}{c}{ Source: (Triunfo 1974, p. 32). }
\end{tabular}

In this context, architecture was confined to a female minority, normally from the few families that retained egalitarian ideas, or from those in which there was an architect in the family (Sánchez de Madariaga 2010). The first woman to finish her architecture studies in Spain was Matilde Ucelay, in 1936; the same year that the Spanish Civil War began (Sánchez de Madariaga 2012; Vilchez 2012). At this time, the Central University of Madrid was the only School of Architecture in the whole country. After Ucelay, three other women studied architecture in Madrid before the Civil War, but only two graduated: Cristina Gonzalo and Rita Fernández-Queimadelos in 1940 (Carreiro-Otero and López-González 2019, p. 198). In the 1950s only four more women finished their studied in architecture in Madrid (ibid., p. 199). The following decade, a second School of Architecture opened its doors. The School of Barcelona (ASB) issued its first degree to a woman in 1962; Margarita Brender Rubira became the first Catalan female architect. At the end of the 1960s, coinciding with Spain's economic development, but still under Franco's regime, the number of female architects increased to around forty, with the inclusion of a new School of Architecture in Seville, which opened its doors in 1958 (Agudo and Madariaga 2011, p. 159).

Franco's gender stereotypes not only affected women's decisions on which career to study, but also affected professional life. The vast majority of married women with higher degree studies chose family life and household work over their profession. Following Durán's data, 27\% of the small number of women studying at Spanish Universities towards the end of the sixties decided to work part-time after finishing their studies, and $11 \%$ declared that would like to work only at some point of their life (Durán 1972, p. 210). In fact, 52\% of unmarried women graduates in 1964 were employed on a full-time basis five years later, $23 \%$ of them were working part-time and also studied, and $9 \%$ worked part-time to be able to attend domestic chores. In contrast, $51 \%$ of married women decided to work part-time to be able to perform household chores and care, and $18 \%$ ultimately never worked. In fact, only $17 \%$ of married women with higher degree studies were employed on a full-time basis (ibid., p. 212).

Between 1966 and 1977, seven new centres offered studies in Architecture in Spain, which opened up possibilities for a greater number of women to study. Six of them-the schools of Valencia (1966), Valladolid (1968), Las Palmas de Gran Canaria (1968), El Vallés (1974, part of ASB), A Coruña (1975), and Basque Country (1977) -were public centres linked to the State. Only one of them, Navarra University (1964), was a private centre, which was, furthermore, linked to Opus Dei, a powerful Catholic organization in the country. This centre would be the only private Architecture School in Spain until the mid-1990s. In this period an average of 700 architects graduated each year between public and private Schools. There is no gender-segregated official data on the increase of architecture students until 1985 yet. What can be confirmed is that the greater number of Architecture Schools in the country meant that the number of architects (men and women) also increased annually. The Spanish Statistical Institute data confirms that in the 1985-1986 academic years, the number of graduate students of architecture was 850 , of which $19 \%$ were now women. This percentage varied depending on the geographical area (Table 2). 
Table 2. Number of men and women graduated in Architecture in 1985-1986, Spain.

\begin{tabular}{ccccc}
\hline & Total & Men & Women & Percentage of Women \\
\hline Madrid U. & 288 & 216 & 72 & $25 \%$ \\
Barcelona + El Vallès & 198 & 165 & 33 & $17 \%$ \\
Sevilla U. & 91 & 80 & 11 & $12 \%$ \\
Navarra U. (private) & 92 & 74 & 18 & $20 \%$ \\
Valencia U. & 92 & 84 & 8 & $9 \%$ \\
Valladolid U. & 31 & 25 & 6 & $19 \%$ \\
Las Palmas U. & 19 & 19 & 0 & $0 \%$ \\
A Coruña U. & 24 & 16 & 8 & $33 \%$ \\
Basque Country U. & 15 & 10 & 5 & $33 \%$ \\
Total & 850 & 689 & 161 & $19 \%$ \\
\hline
\end{tabular}

Source: Spanish Statistical Institute.

As Table 2 shows, the Schools with the longer tradition (Madrid and Barcelona areas) had the highest number of women graduates, almost doubling the total number of women in the rest of Spain. Ten years later, in the 1995-1996 academic year, the number of graduates was 1689, of which 39\% were women (Table 3). At this time, the percentage of women was more even over the whole country. Two years later, in 1997-1998, the 40\% barrier was overcome for the first time with a total of 851 women graduates compared to 1063 men. This percentage progressed slowly upwards until 2011-2012 when it reached $50 \%$. The data available confirms that this parity has remained.

Table 3. Number of men and women graduated in Architecture in 1995-1996, Spain.

\begin{tabular}{ccccc}
\hline & Total & Men & Women & Percentage of Women \\
\hline Madrid U. & 489 & 272 & 217 & $44 \%$ \\
Barcelona + El Vallès & 448 & 273 & 175 & $39 \%$ \\
Sevilla U. & 188 & 120 & 68 & $36 \%$ \\
Navarra U. (private) & 189 & 108 & 81 & $43 \%$ \\
Valencia U. & 112 & 68 & 44 & $39 \%$ \\
Valladolid U. & 87 & 64 & 23 & $26 \%$ \\
Las Palmas U. & 8 & 6 & 2 & $33 \%$ \\
A Coruña U. & 112 & 80 & 32 & $29 \%$ \\
Basque Country U. & 56 & 41 & 15 & $27 \%$ \\
Total & 1689 & 1032 & 657 & $39 \%$ \\
\hline
\end{tabular}

Source: Spanish Statistical Institute.

\section{Women's Education and Their Incorporation into Architectural Studies: The Portuguese Case}

In Portugal, as previously stated, alongside the 1933 Constitution, legislation supporting the corporate State also emerged. Female work outside the home was regulated in detail, considering "questions regarding morality, physical defence, motherhood, domestic life, education and social well-being". Not allowing the presence of women into the professional sphere was a means of guaranteeing jobs for men, since the lower wages paid to women promoted their employment in some industries (Pimentel 2015a, pp. 221-22). The moral aspect of bringing women back to the domestic sphere, serving the Nation and the corporate regime, fixed their central role in solidifying the family institution. Yet this need to keep them from 'stealing' men's jobs is never far from the surface in the way the regime viewed women and the world of labour. Naturally, the censuses show that close to $100 \%$ of women performed domestic services or worked as maids. The censuses also underline that, contrary to what one may expect, there was a significant presence of women in the labour force, mainly until the 1960s, notably in the tobacco, textile, shoe and clothing industries (Pimentel 2001, p. 22). In these cases, the interests of the entrepreneurs easily took precedence over the supposedly higher values of the Nation's morality and economy. 
In the 1940s, there was an expansion of the Portuguese State and its commercial activities, partly made possible by the advantages obtained during the Second World War. In the case of architecture, this was initiated with the 1940 Great Exhibition of the Portuguese World, in Lisbon. This time is marked by the great public works implemented by the minister Duarte Pacheco. Concerning the growing feminization of office work, this is the decade when the foundations of national accounting were laid. This would imply "an effort of bureaucratization demanded from the State, individuals and companies to respond to this new need", which would be reflected in the rapid growth of office jobs, where women's presence clearly increases (if, in 1940, they made up about $11 \%$ of the workforce, by 1960 it had increased to 20\%, by 1970 to 35\% and by 1981 to 42\%) (Ferreira 2001, p. 27). Even though this was a profoundly agricultural country, where, in 1950, almost half of the active population still worked on the land, changes were underway. Between 1950 and 1960 Portugal experienced important changes to its social fabric and labour markets. As mentioned by the sociologist Virgínia Ferreira (ibid., pp. 27-28), as a result of the attractions of basic industries and investment in the construction of infrastructure, the country experienced a significant rural exodus, with the creation of over 40,000 new office jobs, $40 \%$ of which were occupied by women. During the 1960s, two demographic movements will influence the Portuguese social structure. Firstly, with the beginning of the colonial wars in Africa, about 114,000 soldiers were deployed to the continent every year. Secondly, given the country's economic and social conditions, we estimate that roughly half a million Portuguese migrated to other European countries.

In terms of education, there was a slow decrease in illiteracy, with values of $62 \%$ in $1930,49 \%$ in $1940,40 \%$ in 1959 and, in 1960, it went down to 30\%. In this context, the number of illiterate women was always higher than that of men, between 17 and 12 percentage points (Nóvoa 1992, pp. 475-576). High-school education had a significant boost, increasing six-fold between 1930 and 1960, especially in the 1950s. An interesting aspect is the clear explosion in women's representation in schools (in 1960, there were more girls officially enrolled in high school than boys). Families start looking at their daughters' education differently, which coincides with the aforementioned growing feminization of some specialized professional areas (ibid., p. 486). Higher education reveals the prevailing social and classist underrepresentation. Despite this growth, the number of university students remains low and is far from that of high-school students. The rate of feminization, at 19\% in 1940 and at $31 \%$ twenty years later, foretells the direction that the next decades, now under democracy, would reinforce (ibid., p. 494). In Portugal, women's education was always seen as instrumental to the role assigned to them within Salazar's regime: acting as anchors of the family, as well as anchors of a conservative idea of Nation and society.

In the case of Portugal, there is no official detailed data available on the evolution of the number of women graduated in Architecture. Nonetheless, there is relevant data from the Portuguese Association of Architects (AAP). In 1970, the number of architects enrolled in the AAP was under 500, and a little over $5 \%$ were women. In 1980, ten years later, the AAP will have over 186 women architects accepted, and 609 new male members, which proves that women were gaining a clear foothold in the profession. ${ }^{3}$ When Maria José Estanco (1905-1999) received her degree in Architecture from Lisbon's School of Fine Arts, in 1942, some newspapers at the time published short articles mentioning the "first Portuguese lady to whom a degree in Architecture was granted". In Porto, the same happens the following year with Maria José Marques da Silva (1914-1994), the daughter of Marques da Silva, an architect and director of the School of Fine Arts (Pedrosa 2015, pp. 196-98). The aforementioned foundational paradigm became evident in the lives of these two women: Maria José Estanco did not fully enter the profession and worked as a high-school teacher instead; the work that Maria José Marques da Silva had performed in partnership with her husband remained invisible for a long time (Pedrosa 2010, p. 236).

3 According to data from the Portuguese Ordem dos Arquitectos, the numbers of new admissions of women and men were respectively: 1970: 0/19; 1971: 3/19; 1972: 1/32; 1973: 4/36; 1974: 4/53; 1975: 9/59; 1976: 10/56; 1977: 21/87; 1978: 28/103; 1979: 56/77; 1980: 50/118 (October 2018). 
Broadly speaking, more women were gradually becoming university students. In the case of Architecture, until the end of the 1980s, there were only two public schools that offered this subject. During these decades, there was some resistance to these slow changes, similar to what happened in traditionally male training and professions. The numbers demonstrate it and personal stories confirm it. In 2014, an interview with the female Portuguese architect Antonieta Jacinto (born in 1930), revealed her difficulties in enrolling in the school in the 1950s. Apparently, an employee told her that "the director [of the school, architect Luís Cunha] did not like girls" (Monteiro 2015, p. 58). Only her insistence could reverse his resistance. The following question will always remain unresolved: how many women were left out by this informal, but certainly effective, rejection process?

In the 1960s and 1970s, the two Portuguese magazines specialized in architecture, Arquitectura and Binário, presented profound differences in the promotion of texts and projects by women compared to men. Despite having different histories and origins, they coincided in one thing: the presence of women is always rare and, until 1980, did not reflect the current growth of women architects in the profession (Almeida 2017, p. 104) (Table 4).

Table 4. Number of new admission of men and women in Architectural Studies in 1970-1980, Portugal.

\begin{tabular}{ccccc}
\hline Year & Total & Men & Women & Percentage of Women \\
\hline 1970 & 19 & 19 & 0 & $0 \%$ \\
1971 & 22 & 19 & 3 & $14 \%$ \\
1972 & 33 & 32 & 1 & $3 \%$ \\
1973 & 40 & 36 & 4 & $10 \%$ \\
1974 & 57 & 53 & 4 & $7 \%$ \\
1975 & 68 & 59 & 9 & $13 \%$ \\
1976 & 66 & 56 & 10 & $15 \%$ \\
1977 & 108 & 87 & 21 & $19 \%$ \\
1978 & 131 & 103 & 28 & $21 \%$ \\
1979 & 133 & 77 & 56 & $42 \%$ \\
1980 & 168 & 118 & 50 & $30 \%$ \\
\hline \multicolumn{5}{c}{ Source: Ordem dos Arquitectos, Portugal. }
\end{tabular}

When the catalogue of the First National Architecture Exhibition (1975-1985) was published in 1986, from a total of 317 participants, 48 were women architects, which corresponds to roughly $15 \%$. In the analysis of the almost 500 projects that were presented-whether built or not-women appear as co-authors in 57 of them ${ }^{4}$, and they were the sole authors of 38 projects. Upon studying the programs, it reveals that over half of the solo projects were houses, of different complexities. The remaining programs authored by women vary greatly and include urban renewal, offices, schools, and other public facilities (Associação dos Arquitectos Portugueses 1986). This exhibition and its subsequent publication reinforce the idea that Portuguese women architects were working in the field, planning and building across the country and entering architectural programs. This presence, however, is far from being represented in the mainstream history of Portuguese architecture.

In the terms of employment, in the period after 25 April 1975 there was an explosion of the tertiary sector in Portugal, in addition to a significant decrease in migratory movements, with 400,000 thousand people returning to the country, as well as demobilized soldiers (about 100,000) and retornados coming back from Africa (about 225,000). The development of economic activities and the high investment in the public sector, with the resulting job growth, contrasted with what was happening at the time in most of the countries of the Organization for Economic Cooperation and Development (OECD) (Ferreira 2001, pp. 28-29). At the turn of the 1980s, many of the structural questions of inequality between the sexes in the context of work still endured and would not dissipate for a long time. This was visible in the fact that women were not socially accepted into some professions, as well as in the

4 Main co-authors. The women architects who were part of collaborators' team were not considered. 
low-skilled positions they usually occupied, and in the persistence of an income pay gap between women and men. Another important factor during the 1980s was the growing precariousness of employment among women. After an impressive increase in female work in the 1960s and 1970s, from 1983 onwards it stabilized around 40\% (Pimentel 2015b, pp. 386-87).

In a slower process, architecture also witnessed an effective feminization of the profession, and additionally the growing precariousness is being confirmed. Portuguese women architects suffered similar inequalities in their professional careers as in Spain. Although women currently represent almost half of the enrolments in the Ordem dos Arquitectos (OA) and already make up the majority of new students in some architecture courses, they still have a less visible public presence and recognition than is warranted by their numbers.

\section{Women in Architecture: An On-going Field of Research}

The cases of Portugal and Spain bring up the complexities of studying countries that, even when geographically, politically and culturally close, deal with different realities, and, therefore, different states of research. Since the 1970s, the role of women in the architecture profession has been studied mainly in relation with modern architecture and especially in what we could call 'canonical' countries, such as the United States and the United Kingdom, where research on gender studies has a longer tradition than in Portugal and Spain. As we can see from the previous data, to relate modern architecture and Portuguese and Spanish women leads us to pioneer women architects working in countries under regimes with totalitarian gender stereotypes and profound discrimination against women. The mid-1970s is the moment where it is possible to find an increasing number or female architects coincidentally with crucial democratic political and socio-cultural changes that affected their lives. Thus, this text briefly presented those changes and provided some useful data to easily understand the particularities of Portugal and Spain in relation with the delay incorporation of women to the architecture profession in comparison with other 'canonical' countries. Therefore, this special issue aims to create an opportunity for researchers and scholars to present discussions and ongoing research on how those changes affected women that wanted to be architects as well as architectural analysis of their works.

Unfortunately, the inequalities suffered by a high number of women in this profession are still present in both countries - as well as throughout Europe. The last Sector Study report of the Architect's Council of Europe shows that parity in the exercise of the profession varies according to the different European countries: "the majority of the profession continues to be male; 61 per cent of architects are male, 39 per cent are female. Countries which have the highest proportions of male architects include Austria, the Czech Republic, and the Netherlands. Countries with the highest proportion of female architects include Sweden, Greece, Norway, Croatia and Finland" (Architects' Council of Europe 2018, p. 1.12). It confirms that the proportion of women practicing architecture in Spain is $35 \%$, despite having parity in the classroom for almost three decades, while in Portugal parity is almost a reality with $46 \%$ of women practicing architecture. However, the pay gay is broader in Portugal than in Spain. As this report shows, the average in Europe is $25 \%$ in favour of male architects, whereas the pay gap in Portugal is $27 \%$ and in Spain 12\% (Architects' Council of Europe 2018, p. 4.09). Certainly, the state of inequality varies by country but exists in the vast majority of them.

This reality is having significant implications in the field of research. With the fourth wave feminism, there are an increasingly important number of studies that analyse how women worked in the past in order to understand the historical and cultural reasons of the current situation. In the Iberian context, we need to underline the importance that governments and science politics recently gave to gender studies and the history of women in architecture. The funds that research projects as the ones we coordinate are examples of it. Nevertheless it is not enough; it is desirable that in a few years more research will be done, and new questions and arguments will emerge to understand the bases of this gendered profession, to face current inequalities, and to value the work of women in architecture. 
Author Contributions: Conceptualization: L.C.P.-M. and P.S.P.; Funding acquisition: L.C.P.-M. and P.S.P.; Investigation: L.C.P.-M. and P.S.P. Methodology: L.C.P.-M. and P.S.P.; Resources: L.C.P.-M. and P.S.P.; Writing - L.C.P.-M. and P.S.P.; Writing - review \& editing, L.C.P.-M. and P.S.P. All authors have read and agreed to the published version of the manuscript.

Funding: This research was funded by the Spanish Government (Ministry of Science, Innovation and Universities, Grant number: PGC2018-095905-A-I00) and the Portuguese Government (FCT, PTDC/ART-DAQ/32388/2017). Spanish Research Project Title: Women in Spanish (Post)Modern Architecture Culture, 1965-2000. Portuguese Research Project Title: W@RCH.PT, Women Architects in Portugal: Building Visibility, 1942-1986.

Conflicts of Interest: The authors declare no conflict of interest.

\section{References}

Agudo, Yolanda, and Inés Sánchez de Madariaga. 2011. Construyendo un lugar en la profesión: Trayectorias de las arquitecturas españolas. Feminismos 17: 155-81. [CrossRef]

Almeida, Tiago. 2017. Arquitectura e Binário, 1940-1979. As (in)visibilidades das Mulheres na Arquitectura Portuguesa. Master's dissertation, ULHT, Lisbon, Portugal.

Architects' Council of Europe. 2018. The Architectural Profession in Europe 2018-ACE Sector Study. Available online: https://www.ace-cae.eu/fileadmin/New_Upload/7._Publications/Sector_Study/2018/2018_ACE_ Report_EN_FN_1_OK.pdf (accessed on 6 February 2020).

Associação dos Arquitectos Portugueses. 1986. 1. ${ }^{a}$ Exposição Nacional de Arquitectura (1975-1985). Lisbon: Associação dos Arquitectos Portugueses.

Carreiro-Otero, María, and Cándido López-González. 2019. La cocina moderna en la vivienda colectiva española a través de los concursos de arquitectura del periodo 1929-1956. Architecture, City and Environment 13: 183-210. [CrossRef]

Cole, Doris. 1973. From Tipi to Skyscraper: A History of Women in Architecture. Cambridge: The MIT Press.

Durán, María Ángeles. 1972. El trabajo de la Mujer en España. Un Estudio Sociológico. Madrid: Editorial Tecnos.

Ferreira, Virgínia. 2001. A feminização dos escritórios (1940-1980). História 34: 24-29.

Ferro, António. 1935. Salazar. Lisbon: Empresa Nacional de Publicidade.

Gíner, Salvador, and Sebastián Sarasa. 1992. Religión, política y modernidad en España. Revista Internacional de Sociología 1: 9-60.

Ginsborg, Paul. 2003. The family politics of the great dictators. In Family Life in the Twentieth Century. Edited by David I. Kertzer and Marzio Barbagli. New Haven and London: Yale University Press, pp. 174-97.

González Pérez, Teresa. 2009. Los programas escolares y la transmisión de roles en el Franquismo: la educación para la maternidad. Bordón. Revista de Pedagogía 61: 95.

Larumbe, María Ángeles. 2002. Una Inmensa Minoría. Influencia y Feminismo en la Transición. Zaragoza: Prensas Universitarias de Zaragoza.

Larumbe, María Ángeles. 2004. Las que Dijeron no. Palabra y Acción del Feminismo en la Transición. Zaragoza: Prensas Universitarias de Zaragoza.

Monteiro, Paula. 2015. Mulheres invisíveis. Princípios para uma reconstrução do discurso em arquitectura. Urbana: Revista Eletrônica do Centro Interdisciplinar de Estudos sobre a Cidade 7: 55-66.

Moreno, Amparo. 1977. Educación de la mujer: La gran estafa. Vindicación Feminista 10: 29-37.

Nóvoa, António. 1992. A «Educação Nacional». In Nova História de Portugal_Portugal e o Estado Novo (1930-1960). Edited by Fernando Rosas. Lisbon: Editorial Presença, pp. 455-519.

Oliveira, César de. 1992. A revolução política. In Nova História de Portugal_Portugal e o Estado Novo (1930-1960). Edited by Fernando Rosas. Lisbon: Editorial Presença, pp. 21-85.

Pedrosa, Patrícia Santos. 2010. Being a female architect in Portugal: A short introduction to a long ride. In 1st International Meeting EAHN European Architectural History Network-CD of Papers'. Guimarães: CHAM, EAUM, EAHN, pp. 234-40.

Pedrosa, Patrícia Santos. 2015. Mujeres arquitectas en Portugal. In ArquitectAs, Redefiniendo la Profisión. Edited by Nuria Álvarez Lombardero. Seville: Recolectores Urbanos, pp. 189-200.

Pérez-Moreno, Lucía C. 2016. The 'Transition' as a turning point for a female agency in Spanish Architecture. In $A$ Gendered Profession. Edited by Ruth Morrow, Harriet Harriss, Jame Brown and James Soane. London: RIBA, pp. 108-15. 
Picontó, Teresa. 1997. Family Law and Family Policy in Spain. In Family Lay and Family in the New Europe. Edited by Jacek Kurczewski and Mavis Maclean. Oñati: Dartmouth Publishing Company Limited, pp. 109-27.

Pimentel, Irene Flunser. 2001. Cem anos de vida das mulheres em Portugal. História 34: 12-23.

Pimentel, Irene Flunser. 2015a. A fada do lar ainda não é cidadã. A situação das mulheres na I República e no Estado Novo. 1910-1974. In Mulheres Portuguesas. História da vida e dos Direitos das mulheres num Mundo em Mudança. Edited by Irene Flunser Pimentel and Helena Pereira de Melo. Lisbon: Clube do Autor, pp. 171-372.

Pimentel, Irene Flunser. 2015b. Enfim, cidadã. As mulheres na democracia portuguesa. In Mulheres Portuguesas. História da vida e dos Direitos das Mulheres num Mundo em Mudança. Edited by Irene Flunser Pimentel and Helena Pereira de Melo. Lisbon: Clube do Autor, pp. 373-406.

Sánchez de Madariaga, Inés. 2010. Women in architecture: the Spanish case. Urban Research E Practice 3: $203-18$. Sánchez de Madariaga, Inés. 2012. Matilde Ucelay. Una vida en Construcción. Madrid: Ministerio de Fomento.

Sarasúa, Carmen, and Carmen Molinero. 2009. Trabajo y niveles de vida en el Franquismo. Un estado de la cuestión desde una perspectiva de género. In Historia de las Mujeres. Perspectivas Actuales. Edited by Cristina Borderías Mondejar. Barcelona: Icaria, pp. 309-54.

Torre, Susanna. 1977. Women in American Architecture: A Historic and Contemporary Perspective. New York: Watson-Guptill Publishers.

Triunfo. 1974. El trabajo de la mujer en España. January 6, 32-37.

Vilchez, Javier. 2012. Matilde Ucelay. Primera mujer Arquitecta en España. Ph.D. dissertation, Universidad de Granada, Granada, Spain.

(C) 2020 by the authors. Licensee MDPI, Basel, Switzerland. This article is an open access article distributed under the terms and conditions of the Creative Commons Attribution (CC BY) license (http://creativecommons.org/licenses/by/4.0/). 